УЛК 66.067.57:635.41911.48
А. X.-X. Нугманов [A. Kh.-Kh. Nugmanov],

И. ІО. Алексанян [I. Yu. Aleksanyan],

3. М. Арабова [Z. M. Arabova],

O. А. Алексанян [O. A. Aleksanyan]

\section{ВЫЯВЛЕНИЕ КИНЕТИЧЕСКИХ ЗАКОНОМЕРНОСТЕЙ РАЗДЕЛЕНИЯ ВОДОЭМУЛЬСИОННОЙ ШПИНАТНОЙ СУСПЕНЗИИ В ПОЛЕ ГРАВИТАЦИОННЫХ И ЦЕНТРОБЕЖНЫХ СИЛ}

\section{THE DETERMINATION OF KINETIC REGULARITIES OF SEPARATION OF WATER-EMULSION SPINACH SUSPENSION IN THE FIELD OF GRAVITATIONAL AND CENTRIFUGAL FORCES}

ФГБОУ ВО «Астраханский государственный технический университет», г. Астрахань, Россия/ FSBEI HE «Astrakhan State Technical University»

\begin{abstract}
Аннотация. Пищевая натуральная добавка хлорофилл - это зелёный пигмент растений, хороио растворимый $в$ жирах. Эту пигментную субстанцию, имеющую название пищевой краситель хлорофилл и относяцуюся к пищевьм премиксам, получают различньми физико-химическими способами из сырья, как правило, растительного происхождения. Даииый пищевой краситель разрешен практически во всех странах мира и считаетсл безвредньц дла здоровьл. В известиъх способах получения хлорофилла приленяется неэффективная с точки зрения энергосбережения подготовка растительного материала к экстракиии путем его термической сушки, поэтому предложено часть свободной влаги удалять из измельченного сырья механическим способом. Для решения поставленной задачи наиболее полного извлечения хлорофилла из измельченпьх листьев ипината, их иелесообразно подеергнупь предварительному крапковременному замачиванию в эмульсии вода/органический реагент при ультразвуковом воздействии, и далее удалить часть влаги, например, фильтрующии иентрифугированием. После реализации процесса механического отделения эмульсии от измельченных листьев итината и их отюсима, полученный осадок, имеющий пониженную влажсность, является подготовленньци материалом для экстрагирования из него хлорофиллов. Для рационализации процесса фильтрации необходимо оценить структурио-мехапические свойства осаждаемых материалов с иелью определения сопротивления осадка, выбора материала и сопротивления фильтрующей перегородки в зависимости от движущей силь процесса путем решения кинетического дифференцильного уравнения фильтраиии. В даниой статье рассмотрен важиый этап подготовки растительного сырьл к экстрагированию хлорофилла, а именно механическое удаление влаги из осадка, состоящего из понко измельченных листьев ииината, которьй образуется в результате частичного отделения эмульсии после этапа замачивания. Используя опьытные данные и зависимости от скорости вращения рабочего органа центрифуги, после проведения серии экспериментов получень обобщенные уравнения для расчета удельного сопротивления осадка в зависимости от угловой скорости или от соответствующјего ей перепада давления для использования в инженерньх расчетах фильтрующих центрифуг.
\end{abstract}

Ключевые слова: Шпинат, хлорофилл, интенсивность фильтрации, кинетика, отжим, сопротивление осадка, центрифугирование.

Abstract. Chlorophyll is a green plant pigment that is highly soluble in fats. This pigment substance, called the food dye chlorophyll and related to food premixes, is obtained by various physicochemical methods from raw materials, usually of plant origin. This food coloring is allowed in almost all countries of the world and is considered harmless to health. In known methods for producing chlorophyll, preparation of plant material that is inefficient from the point of view of energy conservation is used for extraction by thermal drying, therefore, it is proposed to remove part of the free moisture from the crushed material by mechanical means. To solve the problem of the most complete extraction of chlorophyll from crushed spinach leaves, it is advisable to subject them to preliminary short-term soaking in water / organic reagent emulsion under ultrasonic treatment, and then remove part of the moisture, for example, by filtering centrifugation. After implementing the process of mechanical separation of the emulsion from the crushed spinach leaves and their extraction, the obtained precipitate having reduced moisture is a prepared material for extracting chlorophyll from it. To rationalize the filtration process, it is necessary to evaluate the structural and mechanical properties of the deposited materials in order to determine the sediment resistance, the choice of material and the resistance of the filtering partition depending on the driving force of the process by solving the kinetic differential filtration equation. This article discusses an important stage in the preparation of plant materials for the extraction of chlorophyll, namely, the mechanical removal of moisture from a precipitate consisting of finely ground spinach leaves, which is formed as a result of partial separation of the emulsion after the soaking step. Using experimental data and the dependence on the speed of rotation of the working body of the centrifuge, after a series of experiments, generalized equations were obtained for calculating the specific resistance of the sediment depending on the angular velocity or the corresponding pressure drop for use in engineering calculations of filtering centrifuges.

Key words: spinach, chlorophyll, filtration rate, kinetics, spin, sludge resistance, centrifugation.

Introduction. The choice of rational technological solutions for the preparation of spinach leaves for the extraction of chlorophyll from them is due to the analysis of existing methods for producing chlorophyll extracts from plant materials. In some of the above methods, preparation of the plant material for extraction, which is ineffective from the point of view of energy saving, is used $[8,14]$; here, the process of drying is meant, therefore it is desirable to ex- 
clude thermal moisture removal from the technology, and remove part of the free moisture from the crushed raw material by mechanical means [12].

To solve the problem of more complete extraction of chlorophyll from crushed spinach leaves, it is advisable to subject them to preliminary short-term soaking in water / organic reagent emulsion under ultrasonic treatment. After the soaking procedure, it is necessary to remove part of the moisture from the spinach with a lower energy intensity compared to thermal processes, for example, centrifugation, after which the material can be considered ready for extraction.

Figure 1 shows an operator model of the proposed technology for preparing plant materials (spinach leaves) for subsequent extraction of green pigment readily soluble in fats from it.

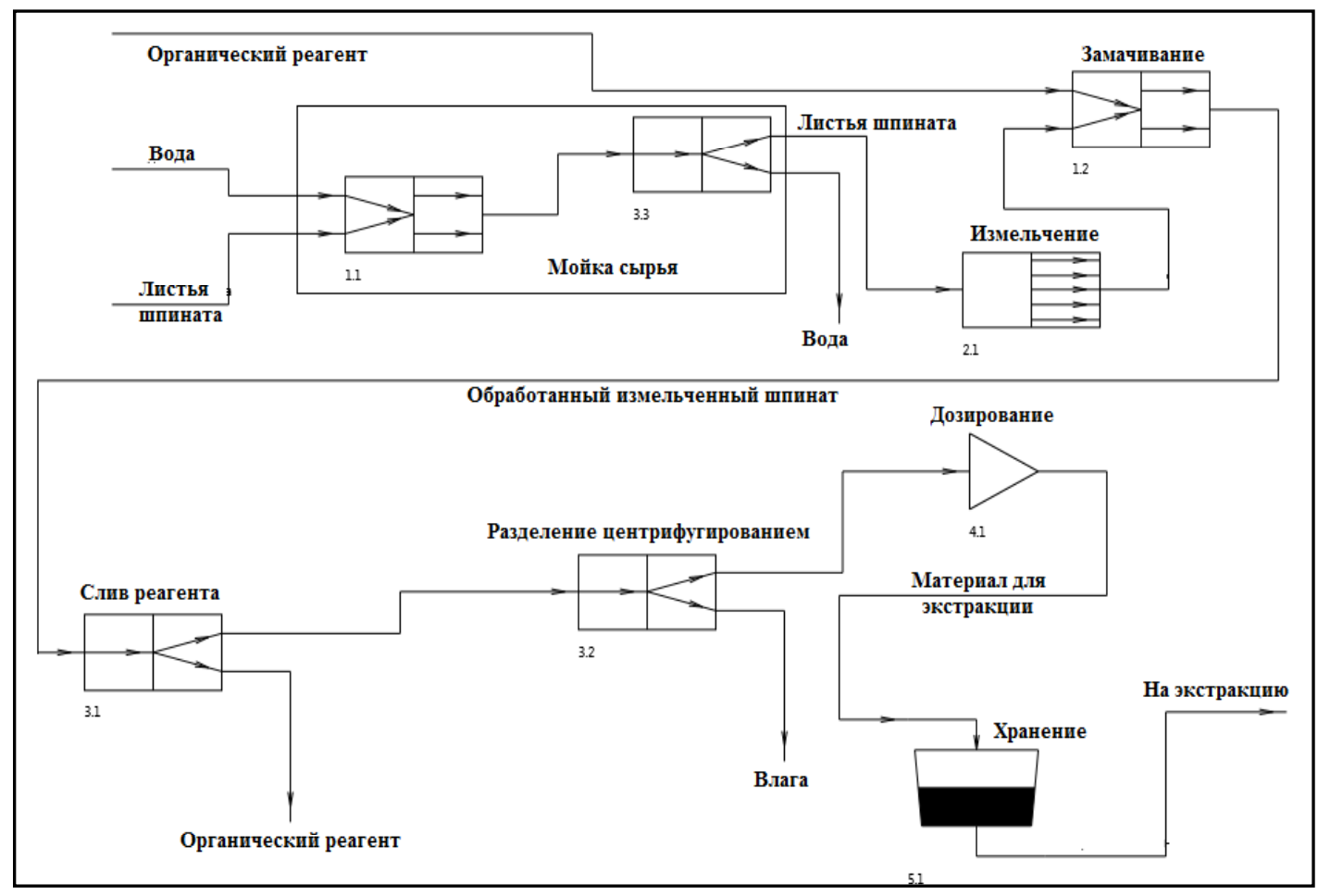

Fig. 1. Operator model of spinach leaf preparation technology to extraction

As already noted, an important stage in the preparation of plant materials is the mechanical removal of moisture from the sediment, consisting of finely chopped spinach leaves, which is formed as a result of partial separation of the emulsion after the soaking step. According to the proposed technology, the process of moisture removal must be carried out under the action of centrifugal forces in special filtering centrifuges to dewater the sludge. Great productivity with a simple design, a continuous sequence of operations and minimal labor costs leads to the widespread use of filtering centrifuges in various industrial fields.

These aggregates are used for clarification of suspensions with a concentration of a dispersed phase of about $50 \%$, rapidly losing their fluidity, as well as for centrifugal extraction. This equipment is an aggregate, including three main nodes:

- a perforated drum located on a horizontal or vertical rapidly rotating shaft, in which the process of filtering the suspension and washing the precipitate;

- a casing in which the filtrate is collected and from which it is removed;

- a drive for rotating the drum with a braking device.

To implement the process of mechanical separation of the emulsion from the crushed spinach leaves and their extraction (processor 3.2 in Fig. 1), continuous filtering centrifuges with a screw device for unloading sludge can be recommended, which are used to dehydrate difficultly transported materials with a high content of fine particles in suspension. The use of devices of this type will allow to obtain products with minimal humidity.

These devices with a conical rotor filter assembly, inside of which a coaxial screw is located, are of vertical (Fig. 2) or horizontal (Fig. 3) design. The screw rotates in the direction of rotation of the rotor with a different frequency and is designed to discharge sediment.

The device diagram shown in Figure 2 is considered standard for vertical machines. Such centrifuges are manufactured with rotor diameters of $200-800 \mathrm{~mm}$ and, as a rule, from 3 to 5 sizes are contained in the parametric row [3, $10]$. 
Horizontal filtering screw centrifuges (Fig. 3) were created in the 50s of the last century, and towards the end of the century their production exceeded the production of vertical centrifuges. Today, around the world, about 30 standard sizes of such centrifuges are manufactured, and their priority over vertical ones is explained by higher operational reliability. Experience shows that horizontal centrifuges are more promising than vertical ones, despite the fact that they occupy a large area and have slightly worse dynamic characteristics (the center of mass of the rotor is located behind the main supports) $[3,10]$.

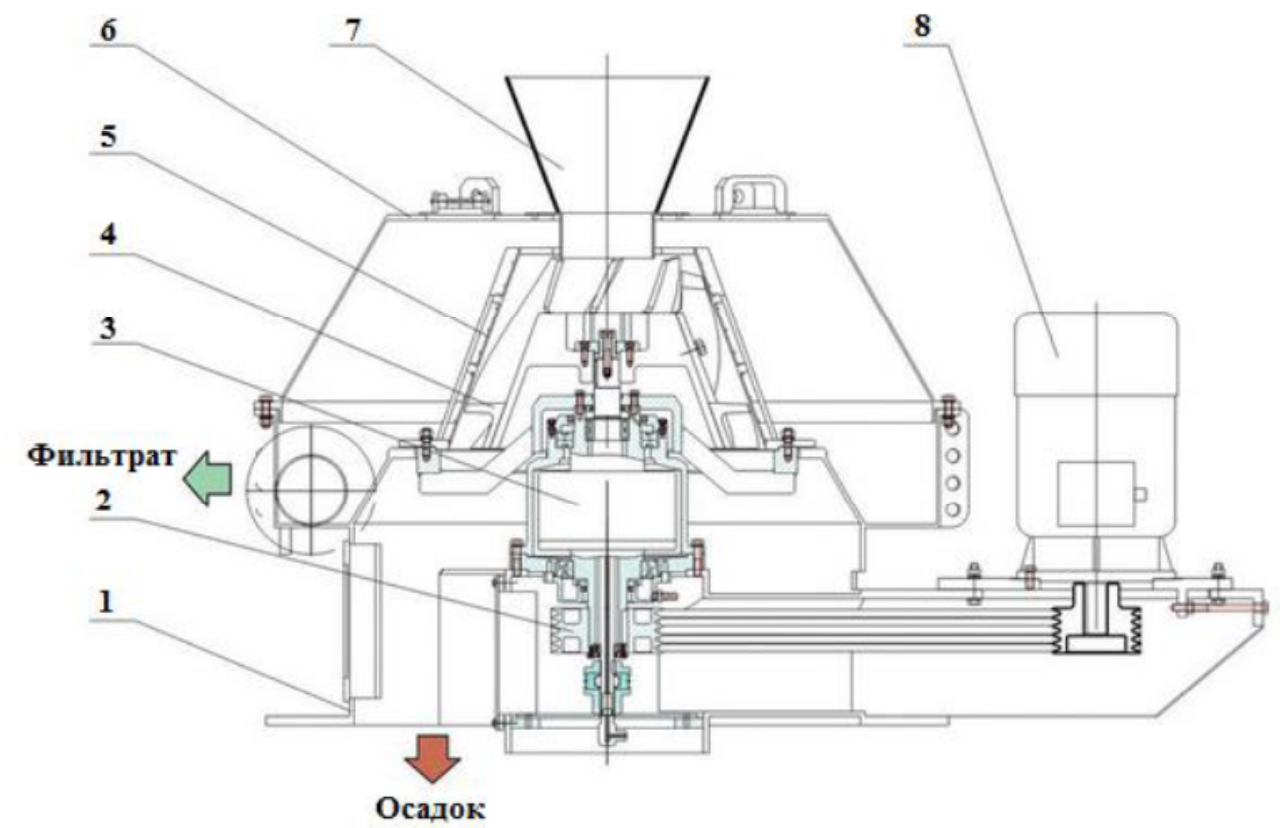

Fig. 2. Diagram of a vertical filtering centrifuge with screw discharge of sediment: 1 - frame; 2 - drive; 3 - gearbox; 4 - spiral scraper; 5 - filtering surface; 6 - case; 7 - loading hopper; 8 - electric motor

After implementing the process of mechanical separation of the emulsion from the crushed spinach leaves and their extraction, the obtained precipitate having reduced moisture is a prepared material for extracting chlorophyll from it.

The preparatory operation for the mechanical removal of moisture from plant materials in the field of centrifugal forces is subject to special attention, because to streamline the filtration process, it is necessary to evaluate the structural and mechanical properties of the deposited materials in order to determine the sediment resistance, the choice of material and the resistance of the filtering partition depending on the driving force of the process by solving kinetic differential equation of filtration.

Goals and objectives. The aim of the study is to determine the specific parameters of the filtration and spin spinach suspension during centrifugation for the selection and calculation of industrial centrifuges.

To achieve this goal it is necessary to solve the following tasks:

1. To analyze the existing methods for producing extracts of chlorophyll from plant materials and the operations of its preparation for extraction.

2. To propose a rational technological and apparatus scheme for preparing raw materials for ekstragirovanie.

3. Theoretically and empirically substantiate the mechanical removal of moisture from the precipitate, consisting of finely chopped spinach leaves, which is formed as a result of partial separation of the emulsion after the soaking step.

4. Using the experimental data and the dependence on the speed of rotation of the working body of the centrifuge, after a series of experiments, obtain generalized equations for calculating the specific resistance of the sediment depending on the angular velocity or the corresponding pressure drop for use in engineering calculations of filtering centrifuges. 


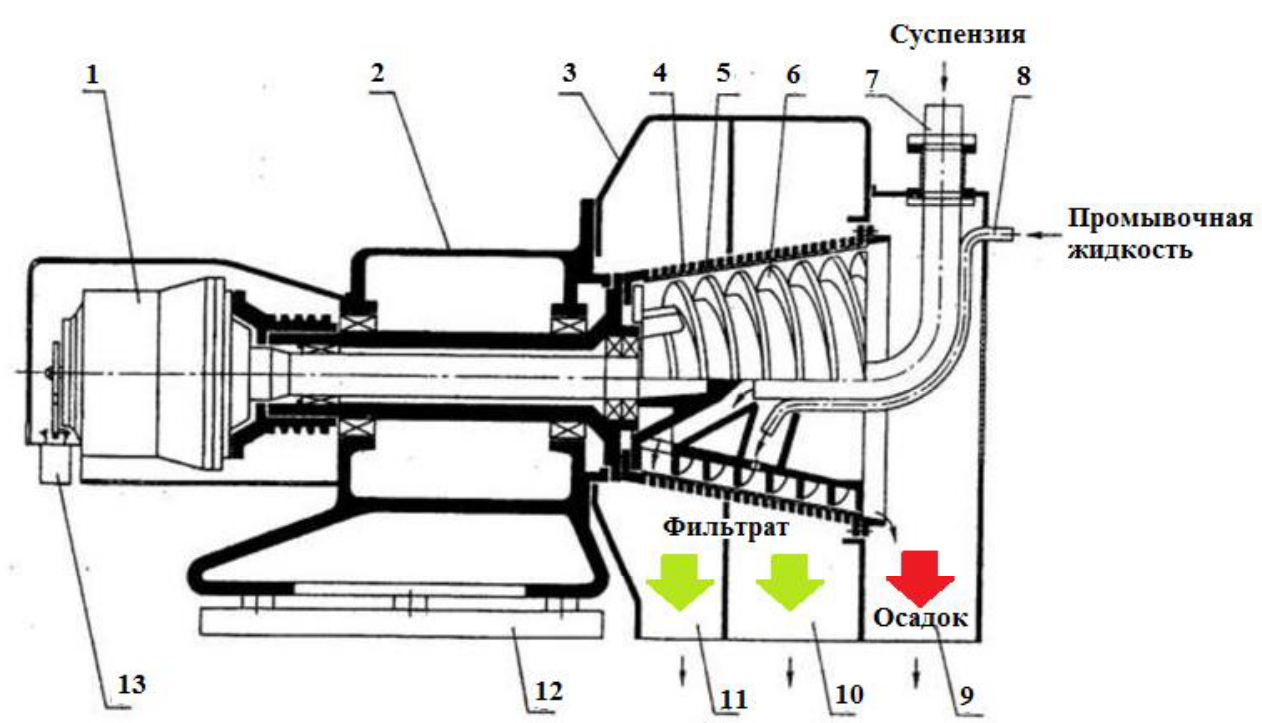

Fig. 3. Scheme of a horizontal filtering centrifuge with auger discharge of sediment: 1 - gearbox; 2 - bed; 3 - a casing; 4 - rotor; 5 - filtering surface; 6 - auger conveyor; 7 - supply pipe; 8 - pipe for entering the washing liquid; 9 - sediment discharge chamber; 10 - chamber drainage of washing fluid; 11 - a chamber for removing the filtrate; 12 - vibration isolating device; 13 - safety device

Methods and Models. Chlorophyll food supplement is a green pigment of plants, highly soluble in fats, plays a key role in photosynthesis, and is vital for the existence of plants. By its structure and structure, chlorophyll is similar to heme (Fig. 4), a non-protein coloring matter of the blood, to which oxygen molecules are attached [2, 7]. In the central part of the porphyrin cycle (Fig. 4 (b)), a magnesium ion is located in chlorophyll, which contacts in the usual interaction with 2 nitrogen atoms, and with other atoms - a coordination bond.

This pigment substance, called food color Chlorophyll (E-140) and related to food premixes, is obtained by various physicochemical methods from raw materials, usually of plant origin. There are also derivative dyes, copper complexes of chlorophylls and chlorophyllins, which are soluble in water and are classified as E-141 by the classification of food additives. As for plant materials, the natural food coloring Chlorophyll is extracted from many of its species, from seaweed to nettles and broccoli, although it is also present in some protozoa and bacteria.

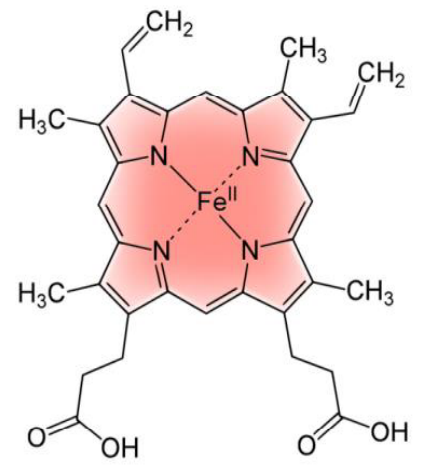

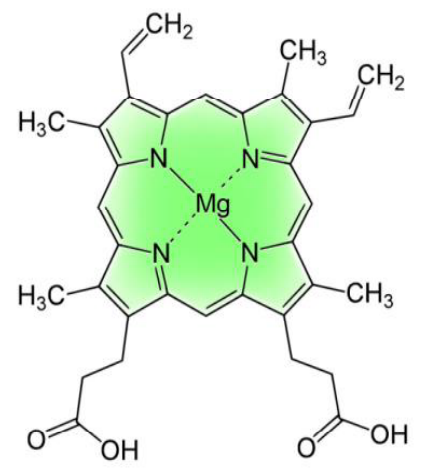

6

Fig. 4. The structure of the porphyrated core of chlorophyll (b) and heme (a)

Food coloring E-140 is allowed in almost all countries of the world and is considered harmless to health, although a scientific discussion on this issue is still relevant. Some consider chlorophyll to be a panacea for all diseases, including oncology and diabetes of both types, while others are of the opinion that chlorophyll can only act as an "air freshener" [9], but the most skeptical researchers still believe that chlorophyll is only a component plants involved in its photosynthesis. As noted above, the structure of chlorophyll is similar to the structure of heme, which forms hemoglobin in conjunction with iron, but there are still structural differences between them, therefore, according to some scientists, chlorophyll is not able to perform the functions of heme, and, therefore, it affects human health slightly [11].

If we are talking about natural chlorophyll, which is in the sap of plants, which can be squeezed out of any edible grass using a conventional mechanical press, then the opinion here is unequivocal - there is no doubt in its healing properties. The absence of this doubt is confirmed by long-term observations of people who consumed medicinal wheat juice, green smoothies and similar drinks for medicinal purposes, and as a result achieved the desired effect, and this includes oncology, and allergies, and immunity, and regeneration, and hormonal levels, etc. As for modern dietary sup- 
plements with chlorophyll, the situation here is not unambiguous, associated with the procedures for their preparation, therefore, when using a PC, the effect may not be, in the best case, if chlorophyll is natural, there is a chance to get the necessary treatment, and in the worst, to throw money away wind and lose time.

In general, it should be noted that the use of synthetic chlorophyll in the food industry does not lead to negative consequences for the finished product, because chlorophyll is one of the safest and sometimes useful food additives used in the industry today.

The choice of spinach leaves as a starting material for obtaining a natural dye based on chlorophylls, in particular, types a and b (Fig. 5, 6), is due to the fact that this vegetable is a food raw material rich in this pigment and, in addition,

a good source of various its functional properties, biologically active substances [4, 13].

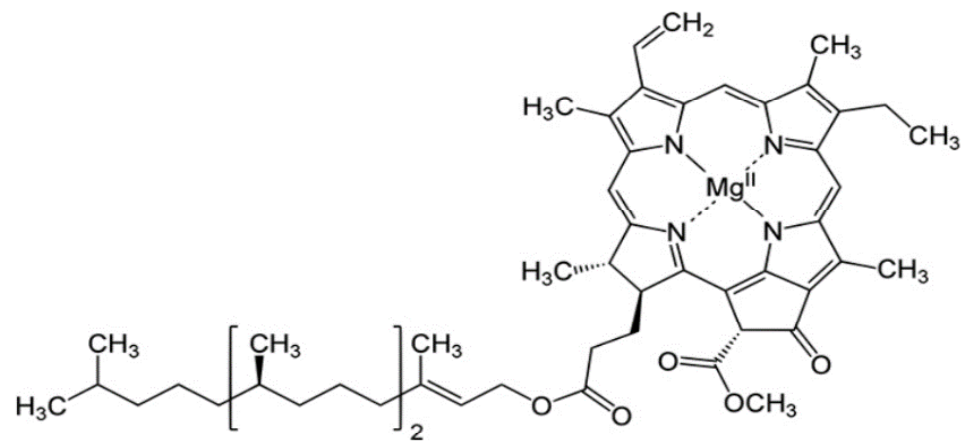

Fig. 5. Chlorophyll of type a

Both chlorophylls in spinach foliage are combined with proteins, and such a common plant complex is called chlorohybin. Both species are soluble in organic solvents, but their solutions are unstable, therefore, after distillation of the extractant, chlorophyll should be dissolved in fats, solutions of which can already be stored.

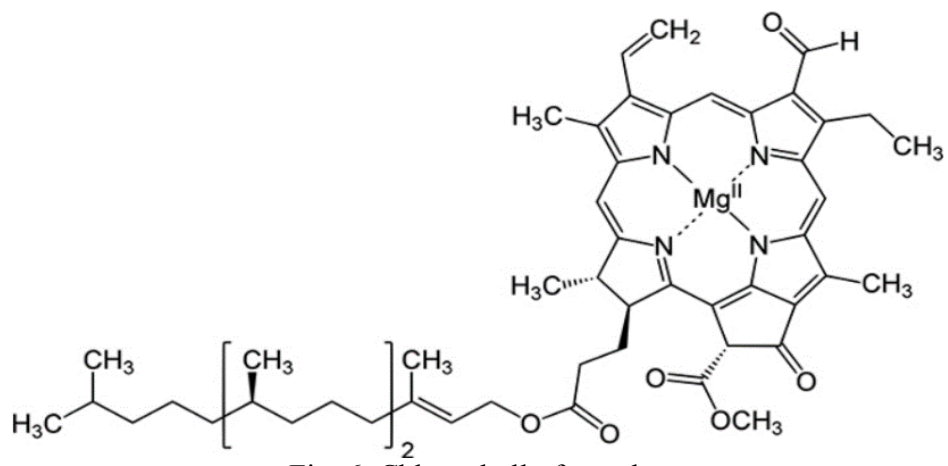

Fig. 6. Chlorophyll of type b

Spinach stands out among the rest of the plant material with a high content of chlorophylls, ascorbic acid, $\beta$ carotene, phenolic compounds, which have an immunomodulating and antioxidant effect. As for chlorophylls, their mass fraction in spinach leaves, according to various sources, ranges from $185 \mathrm{mg}$ to $620 \mathrm{mg}$ per $100 \mathrm{~g}$ of product [5, 6]. Table 1 below provides information on the chemical composition, nutritional value and nutritional balance of fresh spinach.

On the other hand, the choice in favor of spinach is also associated with its large yield with economic suitability after sowing after $25 \div 35$ days with varying varieties. Currently, in the Russian Federation, spinach has not found proper use, although its vegetation interval allows for the supply of fresh vegetable products to the northern regions.

Garden spinach (Spinaciaoleracea) is a 1-year-old dioecious plant that is part of the family of quinoa. It is grown in almost all zones of the Russian Federation, given its early maturity, yield and cold resistance. It is grown at $4^{\circ}$ $\mathrm{C}$, and its shoots and mature plants do not die up to $-6^{\circ} \mathrm{C}$. However, a comfortable temperature for its cultivation is in the region of $15^{\circ} \mathrm{C}$. Harvesting this culture is carried out when sowing in $2 \div 3$ summer period [1].

Table 1

Chemical composition, nutritional value of spinach leaves in $100 \mathrm{~g}$ of product

\begin{tabular}{|l|c|l|l|}
\hline \multicolumn{2}{|c|}{ Serving Size, $\mathrm{g}$} & \multicolumn{1}{c|}{$\mathbf{1 0 0}$} \\
\hline Protein fraction, g & 2,9 & Vitamin K, phylloquinone, mcg \\
\hline Lipid fraction, $\mathrm{g}$ & 0,3 & Vitamin PP, NE, mg \\
\hline Carbohydrate fraction, g & 2 & Niacin, $\mathrm{mg}$ & 1,2 \\
\hline Acid-organic fraction, $\mathrm{g}$ & 0,1 & The presence of macronutrients \\
\hline Food fibers, g & 1,3 & $\mathrm{~K} \mathrm{mg}$ & 0,6 \\
\hline Water component, g & 91,6 & $\mathrm{Ca}, \mathrm{mg}$ & 774 \\
\hline
\end{tabular}




\begin{tabular}{|c|c|c|c|}
\hline Ash component, $\mathrm{g}$ & 1,8 & $\mathrm{Si}, \mathrm{mg}$ & 51,2 \\
\hline Calorie value, kcal & 23 & Mg mg & 82 \\
\hline The presence of vitamins & & $\mathrm{Na}, \mathrm{mg}$ & 24 \\
\hline $\mathrm{A}, \mathrm{RE}, \mathrm{mcg}$ & 750 & $\mathrm{~S} \mathrm{mg}$ & 28,6 \\
\hline Beta Carotene, mg & 4,5 & $\mathrm{Ph} \mathrm{mg}$ & 83 \\
\hline $\mathrm{B} 1$, thiamine, $\mathrm{mg}$ & 0,1 & $\mathrm{Cl} \mathrm{mg}$ & 43,5 \\
\hline $\mathrm{B} 2$, riboflavin, $\mathrm{mg}$ & 0,25 & The presence of digestible carbohydrates & \\
\hline B4, choline, $\mathrm{mg}$ & 18 & Starch and dextrins, $\mathrm{g}$ & 0,1 \\
\hline B5, pantothenic, $\mathrm{mg}$ & 0,3 & Mono- and disaccharides (sugars), $\mathrm{g}$ & 1,9 \\
\hline B6, pyridoxine, mg & 0,1 & Saturated Fatty Acids & \\
\hline B9, folate, mcg & 80 & Saturated Fatty Acids, g & 0,1 \\
\hline $\mathrm{C}$, ascorbic, $\mathrm{mg}$ & 55 & Polyunsaturated Fatty Acids & \\
\hline E mg & 2,5 & Omega-3 fatty acids, $g$ & 0,138 \\
\hline $\mathrm{N}$, biotin, $\mathrm{mcg}$ & 0,1 & Omega-6 fatty acids, $g$ & 0,026 \\
\hline
\end{tabular}

Harvested when the plants appear a small stem and a rosette of $5 \div 8$ leaves is formed. Cleaning is more often disposable, less often selective. The spinach leaves are tender and quickly fade, so when manually harvested, the plants are pulled out with the root and laid down in the lower boxes or baskets. In large areas for cleaning use harvesting machines equipped with a transport trolley.

This vegetable is suitable for use, both raw and after processing. It is used as a salad supplement, pasta, mashed potatoes, various dishes are prepared from it, as well as juice, which is industrially used for tinting green peas when canning it.

Thus, the use of spinach premix for the enrichment of food products with dietary, specialized and therapeutic properties with a high content of biologically active materials leads to significant social effectiveness.

The necessary experimental study of filtering a water emulsion spinach suspension in a centrifugal force field to determine the functional dependence of the filtrate volume on the duration of the process was carried out on a MLWT51 laboratory centrifuge at three speed modes: $\omega_{1}=41,8 c^{-1} ; \omega_{2}=104,6 c^{-1} ; \omega_{3}=209,3 c^{-1}$ (рис. 7).

To find the resistance of the sediment $R_{O C}$ during filtration according to dependence 5 , it is necessary to conduct an additional empirical study on finding the resistance of the filtering partition $R_{\phi}$, which can be determined from relation 1 , where the values included in it are detected empirically.

$$
R_{\phi}=\frac{\rho g h \pi d^{2} \tau}{4 V \mu}
$$

Here $\rho$ - is the density of the liquid phase, $\mathrm{kg} / \mathrm{m}^{3} ; g$ - acceleration of gravity, $\mathrm{m} / \mathrm{s} 2 ; h$ - the height of the liquid column, $\mathrm{m} ; d$ - diameter of the filter partition, $\mathrm{m} ; \tau-$ duration of the experiment, $\mathrm{s} ; V$ - volume of the obtained filtrate, $\mathrm{m} 3 ; \mu$-coefficient of dynamic viscosity of the liquid, $\mathrm{Pa} \cdot \mathrm{s}$.
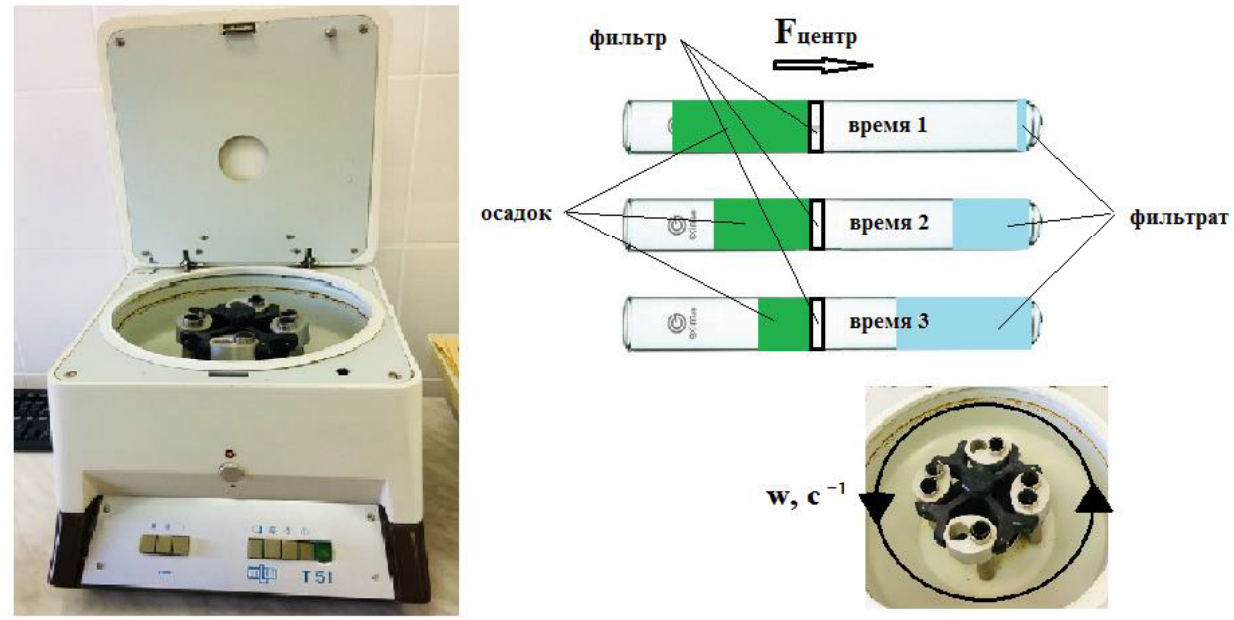

Fig. 7. An experimental study of the filtration of an aqueous emulsion suspension in a centrifugal force field

The essence of the experiment is to determine the obtained filtrate volume with a fixed column of liquid above the filter and for a given duration of the experiment. The experimental setup is shown in Figure 8. In addition, the time and speed of gravitational separation can be determined on this setup. 
A study of the filtration process of an aqueous emulsion suspension in a field of centrifugal forces is necessary to determine the resistance of a compressible precipitate of crushed spinach leaves, which, taking into account the constant resistance of the filtering partition, determines the intensity of the process $W$.

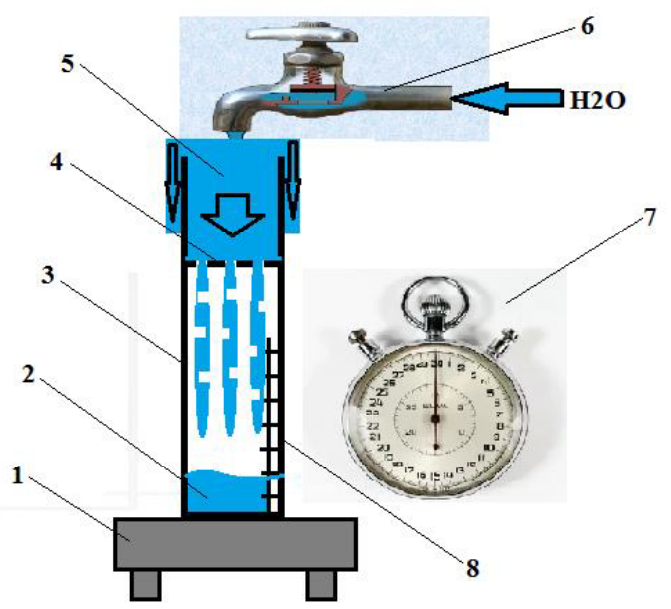

Fig. 8. Installation diagram for determining and the rate of gravitational deposition: 1 - stand; 2 - filtrate; 3 - graduated cylinder; 4 - filtering partition; 5 - water; 6 - node supply fluid to the installation; 7 - stopwatch; 8 - volumetric scale

The classical kinetic differential filtration equation in general terms is represented by the expression:

$$
W=\frac{\partial V}{F \cdot \partial \tau}=\frac{\Delta P}{\mu\left(R_{\dot{\phi}}+R_{O C}\right)}=\frac{\Delta P}{\mu\left(R_{\phi}+r_{O C} h_{O C}\right)},
$$

where $V$ - is the filtrate volume, $\left(\mathrm{m}^{3}\right) ; F$ - area of the filtering partition, $\left(\mathrm{m}^{2}\right) ; \tau-$ the duration of the process, (s); $\mu$ - coefficient of dynamic viscosity of the dispersion phase (filtrate), $(\mathrm{Pa} \cdot \mathrm{s}) ; \Delta P$ - pressure difference before and after the septum (driving force), $(\mathrm{Pa}) ; R_{\phi}$ - resistance of the filtering partition, $(1 / \mathrm{m} 2) ; R_{O C}-$ sediment resistance, $(1 / \mathrm{m})$; $r_{O C}$ - resistivity per unit height of the sediment layer, $\left(1 / \mathrm{m}^{2}\right) ; h_{O C}-$ sediment height, $(\mathrm{m})$.

The filtrate volume can be found as a function of the duration of the process, i.e.:

$$
V_{\tau}=V(\tau)
$$

In this case:

$$
W=\frac{\partial V(\tau)}{F \cdot \partial \tau}
$$

The pressure difference before and after the partition can be determined through centrifugal force $F_{L L}$, which is equal to:

$$
F_{L}=m_{O C} \omega^{2} R
$$

where $m_{O C}-$ is the mass of the dispersed phase (precipitate), $\mathrm{kg} ; \omega-$ the angular velocity of rotation of the working body of the centrifuge, $\mathrm{c}^{-1} ; R=0,12 \mathrm{M}-$ is the radius of the working body of the centrifuge, $\mathrm{m}$

In this case $\Delta P$, it is equal to:

$$
\Delta P=\frac{F_{L I}}{F}=\frac{m_{O C} \omega 0^{2} R}{F},
$$

where, given 2:

$$
\frac{\mu W}{\wedge P}=\frac{1}{R_{\Phi}+R_{O C}}
$$

then:

$$
\frac{\Lambda P}{\mu W}=R_{\Phi}+R_{O C}
$$

From equation 5 we can find the value $R_{O C}$

$$
R_{O C}=\frac{\Delta P}{\mu W}-R_{\Phi}=\frac{m_{O C} \omega^{2} R F}{\partial V(\tau) F \mu} \partial \tau-R_{\Phi} .
$$

The change in the height of the sediment layer $h_{O C}$ during the filtering process can be represented as an empirical linear relationship: 


$$
h_{O C}=a \tau+b,
$$

where $a, b$ - are the experimental coefficients.

Then the resistivity of the unit height of the sediment layer will be equal to:

$$
r_{O C}=\frac{R_{O C}}{a \tau+b}=\frac{\left(\frac{m_{O C}()^{2} R}{\partial V(\tau) \mu} \partial \tau-R_{\Phi}\right)}{(a \tau+b)} .
$$

Considering that the experimental data and dependences are due to the rotation speed of the centrifuge working body, having conducted a series of experiments at various speeds, we can obtain generalized equations for calculation depending on the rotation speed or the corresponding pressure drop for use in engineering calculations of filtering centrifuges.

Results and discussions. An experimental study of filtering an aqueous emulsion suspension in a centrifugal force field to determine the functional dependence of the filtrate volume on the duration of the process was carried out on a MLW-T51 laboratory centrifuge at three speed modes $\varrho_{1}=41,8 c^{-1} ; \omega_{2}=104,6 c^{-1} ; \omega_{3}=209,3 c^{-1}$. The results of the study are presented in table 2 .

Table 2

The Change in the volume of the filtrate depending on the time of the process when filtering $2 \mathrm{~g}$ of raw materials

\begin{tabular}{|c|c|c|c|c|c|c|}
\hline \multirow{3}{*}{$\omega=41,8 \cdot c^{-1}$} & $\tau, \mathbf{c}$ & $\mathbf{0}$ & 20 & 40 & 60 & 120 \\
\hline & $\mathbf{m}, \mathbf{\Gamma}$ & 0 & 0,578 & 0,738 & 0,844 & 0,924 \\
\hline & $V \cdot 10^{6}, \mathrm{M}^{3}$ & 0 & 0,58 & 0,74 & 0,84 & 0,92 \\
\hline \multirow{3}{*}{$\omega=104,6 \cdot c^{-1}$} & $\tau, \mathbf{c}$ & $\mathbf{0}$ & 20 & 40 & 60 & 120 \\
\hline & $\mathbf{m}, \mathbf{\Gamma}$ & 0 & 0,854 & 0,941 & 0,985 & 1,028 \\
\hline & $V \cdot 10^{6}, \mathrm{M}^{3}$ & 0 & 0,85 & 0,94 & 0,96 & 1,03 \\
\hline \multirow{3}{*}{$\omega=209,3 \cdot c^{-1}$} & $\tau, \mathbf{c}$ & $\mathbf{0}$ & 20 & 40 & 60 & 120 \\
\hline & $\mathbf{m}, \mathbf{r}$ & 0 & 0,904 & 0,972 & 1,008 & 1,046 \\
\hline & $V \cdot 10^{6}, \mathrm{u}^{3}$ & 0 & 0,91 & 0,97 & 1,01 & 1,05 \\
\hline
\end{tabular}
at different angular speeds of the working body of the centrifuge

According to the data presented in Table 2, Figure 9 shows the graphical dependences of the change in the filtrate volume on the duration of the process at different angular centrifugation velocities, as well as mathematical approximation curves describing them.

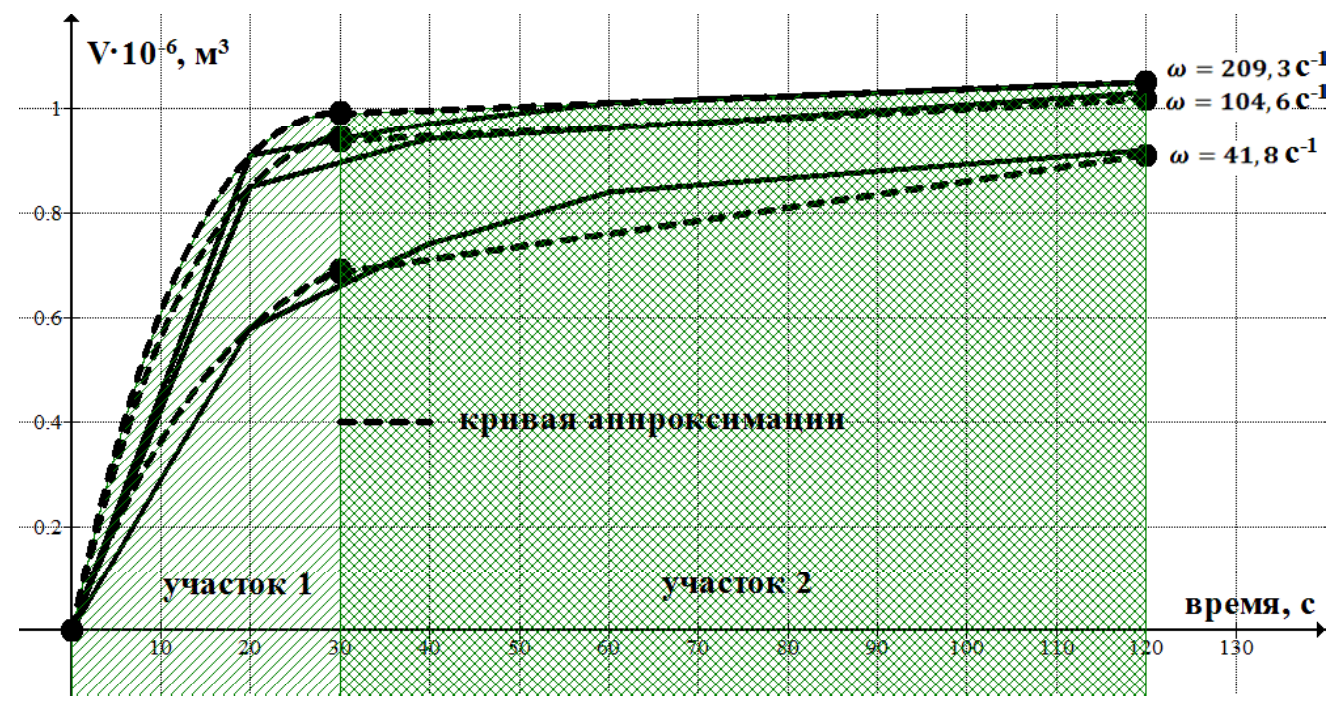

Fig. 9. Graphs of changes in the volume of the filtrate during centrifugal separation of the aqueous emulsion suspension and their mathematical approximation

The results of the mathematical approximation of the empirical dependences of the change in the filtrate volume, on the duration of the process, are presented in table 3 .

Table 3

The result of the mathematical approximation

\begin{tabular}{|c|c|c|}
\hline Mode & Plot 1 & Plot 2 \\
\hline$\omega=41,8 \cdot c^{-1}$ & $V \cdot 10^{6}=7.5 \cdot 10^{-6} \tau^{3}-0.000975 \tau^{2}+0.0455 \tau$ & $V \cdot 10^{6}=0.0025 \tau+0.61$ \\
\hline$\omega=104,6 \cdot c^{-1}$ & $V \cdot 10^{6}=1,4375 \cdot 10^{-5} \tau^{3}-0.0018 \tau^{2}+0.073 \tau$ & $V \cdot 10^{6}=0.0009 \tau+0.91$ \\
\hline
\end{tabular}


An analysis of the graphical dependencies shows that the filtration process takes place in two conditional zones, in the first of which almost the entire filtrate is separated, and after the inflection point the filtration rate drops sharply. As a result of this, it can be concluded that in order to avoid unjustified energy costs, it is advisable to complete the process after passing through the first zone, because the proportion of filtrate in the second zone with respect to its total volume is negligible. In addition, the value of the angular velocity of the working body equal to $105 \mathrm{c}^{-1}$. is rational. Exceeding this value, for example, $200 \mathrm{c}^{-1}$, does not lead to a noticeable increase in the intensity of the process, and a decrease in it leads to a significant decrease in the filtration rate. Thus, for the rational values of the influencing parameters, one can take: $\omega_{p}=105 c^{-1}$ and $\tau=30 c$ (curve 2 in Figure 9).

In this case, the intensity of the filtration process at $\omega_{p}=105 c^{-1}$, according to the obtained ratio of 4 , will have the form:

$$
\begin{aligned}
W=\frac{\partial V(\tau)}{F \cdot \partial \tau} & =\frac{1}{F} \frac{\partial\left(1.4375 \cdot 10^{-11} \tau^{3}-0.18 \cdot 10^{-8} \tau^{2}+0.73 \cdot 10^{-7} \tau\right)}{\partial \tau}, \\
W & =\frac{4.3125 \cdot 10^{-11} \tau^{2}-0.36 \cdot 10^{-8} \tau+0.73 \cdot 10^{-7}}{F},
\end{aligned}
$$

where the area of the filter partition in the experimental setup is equal to:

$$
F=\frac{3.14 \cdot\left(13.5 \cdot 10^{-3}\right)^{2}}{4}=143.07 \cdot 10^{-6}\left(\mu^{2}\right),
$$

then the dependence of the intensity of the process on time will have the form:

$$
W=0.3 \cdot 10^{-6} \tau^{2}-0.25 \cdot 10^{-4} \tau+0.51 \cdot 10^{-3} .
$$

The pressure difference before and after the partition $\Delta P$, which can be determined through centrifugal force $F_{L \zeta}$, is:

$$
\Lambda P=\frac{F_{L}}{F}=\frac{m_{O C} \omega^{2} R}{F}=\frac{0.002 \cdot 105^{2} \cdot 0.12}{143.07 \cdot 10^{-6}}=1.85 \cdot 10^{4}(\Pi a) .
$$

To find the resistance of the sediment $R_{O C}$ according to dependence 5, it is necessary to know the resistance of the filtering partition, $R_{\Phi}$, which was determined from the ratio 1 , where the values included in it were determined experimentally. The values obtained during the experiment at five replicates are summarized in table 4.

Table 4

Values obtained during empirical studies for calculation $R_{\Phi}$.

\begin{tabular}{|c|c|c|c|c|c|}
\hline $\begin{array}{c}\text { Liquid column } \\
\text { height } h, \mathrm{~m}\end{array}$ & $\begin{array}{c}\text { Filter diameter } d, \\
\mathrm{~m}\end{array}$ & Experiment duration $\tau, \mathrm{s}$ & $\begin{array}{c}\text { Filtrate volume } \\
V, \mathrm{~m}^{3}\end{array}$ & $\begin{array}{c}\text { The density of the } \\
\text { liquid } \rho, \mathrm{kg} / \mathrm{m}^{3}\end{array}$ & $\begin{array}{c}\text { Dynamic viscosity of the } \\
\text { liquid } \boldsymbol{\mu}, \mathrm{Pa} \cdot \mathrm{s}\end{array}$ \\
\hline 0,063 & 0,04 & 63 & 0,000016 & 1000 & 0,001 \\
\hline
\end{tabular}

By substituting the experimentally obtained data in a ratio of 1 , the value of the resistance of the filtering partition is obtained:

$$
R_{\Phi}=\frac{1000 \cdot 10 \cdot 0,063 \cdot 3,14 \cdot 0,04^{2} \cdot 63}{4 \cdot 0,000016 \cdot 0,001}=3,12 \cdot 10^{9}(1 / \mathcal{M})
$$

Thus, from equation 5 , knowing the quantity $R_{\Phi}$, we can find the quantity $R_{O C}$ :

$$
\begin{gathered}
R_{O C}=\frac{\Lambda P}{\mu W}-R_{\Phi}=\frac{1,85 \cdot 10^{10}}{0,0003 \tau^{2}-0,025 \tau+0,51}-3,12 \cdot 10^{9}, \\
R_{O C}=\left(1,62 \cdot 10^{-14} \tau^{2}-1,35 \cdot 10^{-12} \tau+2,76 \cdot 10^{-11}\right)^{-1}-3,12 \cdot 10^{9} .
\end{gathered}
$$

The change in the height of the sediment layer $h_{O C}$ during the filtering process can be represented as an empirical linear dependence, due to the small range of changes in the sediment layer and the short time interval of the process:

$$
h_{O C}=-0,00017 \tau+0,032 \text {. }
$$

Then the resistivity of the unit height of the sediment layer, depending on time, according to 6 will be equal to:

$$
r_{O C}=\frac{\left(1,62 \cdot 10^{-14} \tau^{2}-1,35 \cdot 10^{-12} \tau+2,76 \cdot 10^{-11}\right)^{-1}-3,12 \cdot 10^{9}}{-0,00017 \tau+0,032} .
$$


The resulting equation makes it possible to calculate the specific resistance of the sludge at any value of the current process time, as well as to calculate the specific productivity of a real industrial filtering unit for chopped spinach, taking into account the driving force and resistance of the filtering partition in it, using the basic kinetic equation 2.

Conclusion. Thus, when considering the main stage of preparing chopped spinach leaves for extraction of chlorophyll, namely, mechanical removal of moisture from the obtained precipitate, which is formed as a result of partial separation of the emulsion after the soaking stage, it was possible to calculate the specific resistance of the precipitate at any value of the current process time. Moreover, using the materials presented in the article, it is possible to calculate the specific productivity of a real industrial filtering unit for chopped spinach, taking into account the driving force and resistance of the filtering partition in it.

Of interest is the calculation method presented in the article, according to which, using the obtained experimental data and the dependences due to the rotation speed of the centrifuge working body, after conducting a series of experiments at different speeds, it is possible to obtain generalized equations for calculating the specific resistance of the sediment depending on the angular velocity or on the corresponding differential pressure for use in engineering calculations of filtering centrifuges.

\section{ЛИТЕРА ТУРА}

1. Авдеенко С.С. Опыт вырашивания шпината в Ростовской области // Фундаментальные исследования. 2012. № 11-2. C. 341-344.

2. Кабашникова Л. Хлорофилл - зеленое вещество жизни // Наука и инновации. 2018. № 1 (179). С. $65-69$.

3. Касаткин А.Г. Основные процессы и аппараты химической технологии: учеб. для вузов. 11-е изд. М.: ООО ТИД Альянс, 2005. $753 \mathrm{c}$.

4. Лимарева I.С., Донченко Л.В. Функциональные пектиносо-держащие напитки на основе шпината // Современная наука и инновации. 2016. №4. С. 99-104.

5. Миронова К.И., Землякова Е.С. Изучение химического состава растительных экстрактов, положительно влияющих на зрительную функцию // Вестник молодежной науки. 2015. С. 1-7.

6. Морина Н.С., Сидорова Ю.С., Нечаев А.П. Содержание полифенолов в водном экстракте пाпината // Хранение и переработка сельхозсырья. 2016. №1. С. 19-22.

7. Общая характеристика натурального пищевого красителя Хлорофилл. URL:http:/bazadobavok.ru/pishevyedobavki/e100-199/e140-hlorofill.php (Дата обращения: 21.11.2019).

8. Пат. РФ 2496813 Рос. Федерация, МПК С09В 61/00 (2006.01). Способ получения хлорофилла из высших водных растений / М.Д. Мукатова, М.И. Кабанин, А.Р. Салиева; заявл. 22.12.2011, опубл. 27.10.2013, Бюл. №30.

9. Пищевой краситель хлорофил. (хлорофиллин) - добавка E-140. URL: http://bazadobavok.ru/pishevyedobavki/e100-199/e140-hlorofill.php (Дата обрапения: 21.11.2019).

10. Шкоропад, Д.Е., Новиков О.П. Центрифуги и сепараторы для химических производств. М.: Химия, 1987. $256 \mathrm{c.}$

11. Чекунова, Е.М. Генетический контроль метаболизма хлорофиллов // Экологическая генетика. Том XI. №3. 2013. C. 14-27.

12. Zhang, Z.-H., Peng, H., Woo, M.W., Zeng, X.-A., Brennan, M., Brennan, C.S. Preparation and characterization of whey protein isolatechlorophyll microcapsules by spray drying: Effect of WPI ratios on the physicochemical and antioxidant properties (Article) // Journal of Food Engineering. - Volume 267. - February 2020.

13. Roberts J.L., Moreau R. Functional properties of spinach (Spinaciaoleracea L.) phytochemicals and bioactives // Food Funct. 2016. Aug 10. 7(8). P. 3337-3353.

14. Q H Tran, T Q Pham, H T Vu, D X Le, O T Tran, A Q Ngo, T D Nguyen, B T Hoang and S T Do Research on some factors affecting extraction of chlorophyll from mulberry leaves (Morus alba) // IOP Conference Series: Materials Science and Engineering. Volume 479. Number 1.

\section{REFERENCES}

1. Avdeenko S.S. Opyt vyrashchivaniya shpinata v Rostovskoy oblasti // Fundamental'nye issledovaniya. 2012. - № 11-2. S. 341-344.

2. Kabashnikova L. Khlorofill - zelenoe veshchestvo zhizni // Nauka i innovatsii. 2018. № 1 (179). S. 65-69.

3. Kasatkin A.G. Osnovnye protsessy i apparaty khimicheskoy tekhnologii: ucheb. dlya vuzov. 11-e izd. M.: OOO TID Al'yans, 2005. $753 \mathrm{~s}$.

4. Limareva N.S., Donchenko L.V. Funktsional'nye pektinoso-derzhashchie napitki na osnove shpinata // Sovremennaya nauka i innovatsii. 2016. №4. S. 99-104.

5. Mironova K.I., Zemlyakova E.S. Izuchenie khimicheskogo sostava rastitel'nykh ehkstraktov, polozhitel'no vliyayushchikh na zritel'nuyu funktsiyu // Vestnik molodezhnoy nauki. 2015. S. 1-7.

6. Morina N.S., Sidorova YU.S., Nechaev A.P. Soderzhanie polifenolov v vodnom ehkstrakte shpinata // Khranenie i pererabotka sel'khozsyr'ya. 2016. №1. S. 19-22.

7. Obshchaya kharakteristika natural'nogo pishchevogo krasitelya Khlorofill. URL:http://bazadobavok.ru/pishevyedobavki/e100-199/e140-hlorofill.php (Data obrashcheniya: 21.11.2019).

8. Pat. RF 2496813 Ros. Federatsiya, MPK C09B 61/00 (2006.01). Sposob polucheniya khlorofilla iz vysshikh vodnykh rasteniy / M.D. Mukatova, M.I. Kabanin, A.R. Salieva; zayavl. 22.12.2011, opubl. 27.10.2013, Byul. №30.

9. Pishchevoy krasitel' khlorofill (khlorofillin) - dobavka E-140. URL: http://bazadobavok.ru/pishevye-dobavki/e100199/e140-hlorofill.php (Data obrashcheniya: 21.11.2019).

10. Shkoropad, D.E., Novikov O.P. Tsentrifugi i separatory dlya khimicheskikh proizvodstv. M.: Khimiya, 1987. 256 s. 

S. 14-27.

11. Chekunova, E.M. Geneticheskiy kontrol' metabolizma khlorofillov// Ehkologicheskaya genetika. Tom XI. №3. 2013.

12. Zhang, Z.-H., Peng, H., Woo, M.W., Zeng, X.-A., Brennan, M., Brennan, C.S. Preparation and characterization of whey protein isolatechlorophyll microcapsules by spray drying: Effect of WPI ratios on the physicochemical and antioxidant properties (Article) // Journal of Food Engineering. Volume 267. February 2020.

13. Roberts J.L., Moreau R. Functional properties of spinach (Spinaciaoleracea L.) phytochemicals and bioactives // Food Funct. 2016. Aug 10. 7(8). P. 3337-3353.

14. Q H Tran, T Q Pham, H T Vu, D X Le, O T Tran, A Q Ngo, T D Nguyen, B T Hoang and S T Do Research on some factors affecting extraction of chlorophyll from mulberry leaves (Morus alba) // IOP Conference Series: Materials Science and Engineering. Volume 479. Number 1.

\section{OБ ABTOPAX | ABOUT AUTHORS}

Нугманов А.льберт Хамед-Харисович, доктор технических наук, доцент, профессор кафедры «Технологические машины и оборудование», ФГБОУ ВО «АГТУ». albert909@yandex.ru, 8-927-282-43-

07

Nugmanov Albert Khamed-Kharisovich, Doctor of Technical Sciences, Docent, Professor of Department of Technological Machines and Machinery, FSBEI HE Astrakhan State Technical University. albert909@yandex.ru, 8-927-282-43-07

Алексанян Игорь Юрьевич, доктор технических наук, профессор, профессор кафедры «Технологические машины и оборудование», ФГБОУ ВО «АГТУ». 16081960igor@gmail.com, 8-927-282-43-07

ical

Aleksanian Igor Yuryevich, Doctor of Technical Sciences, Professor, Professor of Department of Technolog-

Machines and Machinery, FSBEI HE Astrakhan State Technical University. 16081960igor@gmail.com, 8-927-282-43-07

Арабова Зарема Михай.ловна, ассистент, ФГБОУ ВО «АГТУ», кафедра «Технологические машины и оборудование». albert909@уаndex.ru, 8-927-282-43-07

Arabova Zarema Mikhailovna, Assistant, FSBEI HE Astrakhan State Technical University, Department of Technological Machines and Machinery. albert909@yandex.ru, 8-927-282-43-07

Алексанян Оксана Александровна, аспирант, ФГБОУ ВО «АГТУ», кафедра «Технологические маІшины

и оборудование». albert909@yandex.ru, 8-927-282-43-07

Aleksanyan Oksana Aleksandrovna, Graduate student, SBEI HE Astrakhan State Technical University, Department of Technological Machines and Machinery. albert909@yandex.ru, 8-927-282-43-07 